JAMP: Jurnal Adminitrasi dan Manajemen Pendidikan

Volume 2 Nomor 2 Juni 2019, Hal : 4955

Tersedia Online di http://journal2.um.ac.id/index.php/jamp/

ISSN 2615-8574 (online)

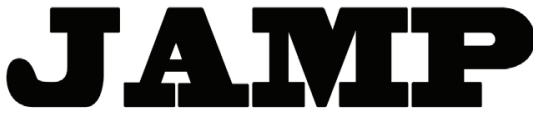

JURNAL ADMINISTRASI DAN MANAJEMEN PENDIDIKAN

\title{
KEPEMIMPINAN KEPALA SEKOLAH DALAM PEMBUATAN KEPUTUSAN DI SEKOLAH BERBASIS PESANTREN
}

\author{
M. Khoirul Anam \\ Mustiningsih \\ Raden Bambang Sumarsono \\ anam.khoiru10206@gmail.com \\ Universitas Negeri Malang, Jl. Semarang 5 Malang 65145
}

\begin{abstract}
Abstrack: This study aims to describe the types of decision-making in school-based schools, the role of principals as leaders in decision-making at boarding schools, school principals in decision-making at boarding schools and the obstacles and solutions of school principals in decision-making in school-based boarding school. The method used in this study is a qualitative approach with a type of case study research. While the procedure for collecting data in this study uses observation, interview, and documentation techniques. The results obtained from this study are: (1) the types of decisions in the boarding school-based schools are in two categories, namely the decisions of the principal and decisions of the caregiver of the foundation; (2) the role of the principal as a leader in making decision-making at the boarding school-based school is that there are two roles that are carried out, namely as the absolute decision maker in the academic field of the school and the liaison role between the school and the foundation;

(3) principals' procedures for making decisions at boarding schools based on: conducting leadership meetings, carrying out draft analysis of planning, submitting to the foundation (if the decision is related to the foundation), alternative decision-making, selected alternatives, and implementing decisions; (4) the type of leadership of the principal in making decisions in boarding school-based schools is: democratic, authoritarian and familial; and (5) school principals' constraints and solutions in decision making at boarding schools based on: first, there are guidelines from foundations that narrow down the decision-making movements in schools so that when making decisions the principal always tries to be guided by the rules that have been made from foundation. Secondly, foundation decisions that are difficult to carry out on the ground and the solution to the school remains as much as possible carrying out decisions that come directly from the foundation. Third, the existence of pros and cons related to the implementation of new decisions was decided at school so that the school principal always provided information and explanations regarding the decisions recently decided on for the school.
\end{abstract}

Keywords: Principal leadership, decision making, boarding school based

Abstrak: Penelitian ini bertujuan untuk mendeskripsikan jenis-jenis pembuatan keputusan di sekolah berbasis peantren, peran kepala sekolah sebagai pemimpin dalam pembuataan keputusan di sekolah berbasis pesantren, prosedur kepala sekolh dalam pembuatan keputusan di sekolah berbasis pesantren serta kendala dan solusi kepala sekolah dalam pembuatan keputusan di sekolah berbasis pesantren. Metode yang digunakan dalam penelitian ini adalah pendekatan kualitatif dengan jenis penelitian studi kasus. Sedangkan prosedur pengumpulan data dalam penelitian ini menggunakan teknik observasi, wawancara, dan dokumentasi. Hasil yang diperoleh dari penelitian ini adalah: (1) jenis keputusan di sekolah berbasis pesantren itu ada dua kategori yaitu keputusan dari kepala sekolah dan keputusan dari pengasuh yayasan; (2) peran kepala sekolah sebagai pemimpin dalam pembuataan keputusan disekolah berbasis pesantren itu ada dua peran yang dilakukan yaitu sebagai pengambil keputusan mutlak dalam bidang akademik sekolah dan peran penghubung antara sekolah dengan pihak yayasan; (3) 


\begin{abstract}
prosedur kepala sekolah dalam pembuatan keputusan di sekolah berbasis pesantren yaitu: melakukan rapat pimpinan, melakukan analisis perencanaan penyusunan konsep, pengajuan kepada pihak yayasan (apabila keputusan menyangkut dengan yayasan), alternatif pemecahan keputusan, alternatif terpilih, dan implementasi keputusan; (4) tipe kepemimpinan kepala sekolah dalam pembuatan keputusan di sekolah berbasisi pesantren adalah: demokratis, otoriter, dan kekeluargaaan; dan (5) kendala dan solusi kepala sekolah dalam pembuataan keputusan di sekolah berbasis pesantren yaitu: pertama, adanya pedoman dari yayasan yang mempersempit dalam pergerakan pembuatan keputusan di sekolah sehingga pada saat pembuatan keputusan kepala sekolah selalu berusaha berpedoman kepada aturan-aturan yang telah dibuat dari yayasan. Kedua, keputusan yayasan yang sulit dilakukan di lapangan dan solusinya sekolah tetap semaksimal mungkin menjalankan keputusan yang turun langsung dari yayasan tersebut. Ketiga, adanya pro dan kontra terkait pelaksanaan keputusan yang baru diputuskan di sekolah sehingga kepala sekolah selalu memberikan sosialisasi dan penjelasan terkait keputusan yang baru diputuskan untuk sekolah tersebut.
\end{abstract}

Kata kunci: kepemimpinan kepala sekolah, pembuatan keputusan, sekolah berbasis pesantren

Kepemimpinan merupakan salah satu yang menetukan keberhasilan suatu organisasi. Menurut Rivai (2004: 3) kepemimpinan adalah seni mempengaruhi dan mengarahkan orang lain agar patuh dan mau menjalankan apa yang akan diperintahnya untuk mencapai tujuan yang telah ditetapkan bersama". Agar dapat menghasilakan tujuan yang produktif, pemimpin organsasi dituntut memiliki kompetensi untuk mengambangkan sebuah lembaga atau organisasi agar dapat lebih meningkat. Maju mundurnya perkembangan organisasi/lembaga sekolah dipengaruhi oleh baik dan tidaknya seorang pemimpin, yang apabila didalam sekolah adalah seorang kepala sekolah. Menurut Mangkawimbang (2010: 61) kepala sekolah merupakan seorang fungsional guru yang diberi tugas untuk memimpin suatu sekolah yang didalamnya diselenggrakan proses belajar mengajar atau tempat terjadinya pembelajaran interaksi antara guru dengan murid. Tuntutan tersebut muncul dikarenakan kepala sekolah dipandang sebagai pemimpin disebuah lembaga tersebut. Sehingga Nurkholis (2008: 174) bahwa kepemimpinan adalah salah satu bagian terpenting dalam manajemen.

Diantara peran terpenting kepala sekolah sebagai pemimpin dalam lembaga pendidikan adalah sebagai pembuatan keputusan tertinggi dalam lembaga yang dipimpin. menurut Mohajeran and Ghaleei (2008) mengemukakan bahwa kepala sekolah adalah pemimpin dalam lembaga pendidikan yang menjadi puncak saat pengambilan keputusan di sekolah. Pembuatan keputusan ini menjadi kunci untuk kebijakan-kebijakan penentu dalam lembaga tersebut. Dengan keputusan yang matang dan baik maka dapat dipastikan sebuah lembaga akan berjalan dengan baik dan lancar sesuai dengan tujuan yang akan dicapai secara bersama-sama. Sehingga pembuatan keputusan ini menjadi sangat penting yang harus dilakukan pemimpin karena keputusan itulah yang akan memberikan dampak yang besar bagi sekolah baik untuk masa jangka pendek maupun nantinya dijangka panjang. Sehingga Schermerhorn, dkk., (2011) mengemukakan bahwa Pengambilan keputusan adalah sebuah proses dari memilih rangkaian tindakan berhubungan dengan masalah atau kesempatan.

Dalam sebuah pembuatan keputusan Simon 1997 (dalam Mustiningsih, 2014: 59) menggambarkan bahwa proses pembuatan keputusan terdiri atas tiga langkah diantaranya, (1) identifikasi dan pemilihan masalah, (2) pengembangan alternatif pemecahan masalah, dan (3) memilih alternatif pemecahan yang terbaik. Selain itu menurut Stoner (dalam Engkoswara \& Komariyah, 2010: 112) mengemukakan bahwa ada beberapa langkah dalam pembuatan keputusan yaitu: (1) Definisi masalah, (2) diagnosis penyebabnya, (3) menentukan tujuan keputusan, (4) mengembangkan alternatif, (5) memilih alternatif terbaik, dan (6) implementasi keputusan.

Apabila dilembaga pendidikan sekolah umum peran pembuatan keputusan tertinggi hanya ada pada kepala sekolah. Akan tetapi lain halnya dengan SMP An-nur Bululawang yang dalam hal ini sekolah tersebut berada dibawah naungan yayasan pesantren An-nur Bululawang. Menurut Suhardi, 2012 bahwa sekolah berbasis pesantren adalah sistem pendidikan unggulan yang merupakan perpaduan antara dua 
sistem pendidikan yang telah dimiliki oleh Indonesia saat ini, yaitu sistem pendidikan formal dan sistem pendidikan pondok pesantren.

Peneliti juga menemukan terkait dengan penelitan sebelumnya yang dilakukan oleh Danang Rizky Permadani dalam skripsinya yang berjudul tentang "Kepemimpinan dalam Pembuatan Keputusan oleh Kepala Sekolah di yayasan Tarbiyatun Nasyi'in Wates Kabupaten Kediri dengan memperoleh hasil bahwa dalam pembuatan keputusan kepala sekolah dalam kepemimpinannya berperan sebagai berikut : (a) peran regulatif. Artinya kepala sekolah dalam rangka menegakkan aturan kepegawaian maupun kependidikan; (b) peran demokratif. Misalnya kebijakan yang menyangkut kepentingan sekolah secara mandiri (seluruh warga sekolah) tidak melibatkan institusi lain; dan (c) peran persuasif. Artinya peran kepala sekolah dalam pembuatan keputusan yang bersifat manusiawi.

Pada pelitian ini peneliti mengungkap kepemimpinan kepala sekolah dalam pembuatan keputusan di sekolah berbasis pesantren yang mana penelitian ini dilakukan di SMP An-Nur Bululawang Kabupaten Malang. di SMP An-Nur Bululawang ini terdapat dua kedudukan kepemimpinan dalam pembuatan keputusan untuk sekolah yaitu seorang kepala sekolah dan pengasuh yayasan An-Nur Bululawang. Sehingga nanti akan diketahui bagaimana kepmimpinan kepala sekolah dalam pembuatan keputusan di sekolah berbasis pesantren tersebut.

\section{METODE}

Penelitian ini menggunakan pendekatan kualitatif dengan jenis rancangan penelitian studi kasus, yang bermaksud untuk mendeskripsikan kepemimpinan kepala sekolah dalam pembuatan keputusan di SMP An-Nur Bululawang Malang melalui penggalian informasi secara mendalam sesuai dengan fokus penelitian yang telah di tentukan sebelumnya. Fokus yang diteliti dalam penelitian kualitatif lebih banyak mencakup proses, oleh karena itu meneliti tentang proses memerlukan pengamatan yang mendalam dan utuh (Ulfatin, 2015: 29).

Peneliti berperan sebagai instrumen kunci dalam proses pengumpulan data. Lokasi penelitian dilakukan di SMP An-Nur Bululawang Malang. Sumber data terdiri dari dua jenis, yaitu data primer dan data sekunder. Data primer pada penelitian ini terdiri dari informan kunci (Kepal Sekolah) dan informan lainnya (Wakil Kepala Sekolah, kepala urusan, guru dan peserta didik). Sedangkan data sekunder dalam penelitian ini berupa hasil pengamatan peneliti dan dokumen pendukung yang relevan dengan fokus penelitian

Teknik pengumpulan data diperoleh peneliti dari hasil observasi, wawancara mendalam, dan dokumentasi. Analisi data yang digunakan dalam penelitian ini mengacu pada model siklus yang digambarkan oleh Miles, Huberman \& Saldana (2014). Kegiatan analisis data dimulai dari mereduksi data dengan cara memberikan kode pada hasil temuan penelitian. Langkah analisis data selanjutnya yaitu display penyajian yaitu dengan cara menyajikan data yang telah diperoleh berdasarkan kepentingan kemudian disajikan melalui bagan atau flowchart agar lebih mudah dipahami, dan langkah terakhir yaitu penarikan kesimpulan pada masing-masing temuan sesuai dengan fokus penelitian. Untuk menjaga keabsahan data, dilakukan dengan uji kredibilitas yang terdiri dari triangulasi sumber dan triangulasi teknik, meningkatkan ketekunan pengamatan serta pengecekan anggota (member checks).

\section{HASIL}

\section{Jenis-jenis keputusan di sekolah berbasis pesantren}

Hasil penelitian menunjukkan bahwa jenis keputusan di SMP An-Nur Bululawng Malang itu ada dua jenis kategori keputusan pertama apabila keputusan yang jenisnya akademik sekolah tanpa menyangkut kegiatan yayasan maka keputusan mutlak ada pada kepala sekolah sebagai pemimpin dan pengambil keputusan utama di SMP An-Nur Bululawang malang. kedua peneliti menemukan bahwa untuk keputusan sekolah yang menyangkut dengan kegiatan yayasan maka keputusan tidak hanya 
sampai di kepala sekolah saja melainkan kepala sekolah masih mengajukan kepada pihak pengasuh yayasan sehingga disini keputusan dan masukan juga bergantung pada pihak pengasuh yayasan.

keputusan yang langsung turun dari pengasuh yayasan untuk sekolah itu adalah keputusan mutlak juga dan harus dikerjakan oleh sekolah sehingga sekolah mau tidak mau harus menjalankan keputusan yang langsung turun dari pengasuh yayasan itu.

\section{Peran kepala sekolah dalam pembuatan keputusan di sekolah berbasis pesantren}

Hasil penelitian menunjukkan bahwa dalam pembutan keputusan di SMP An-Nur Bululawang ini kepala sekolah melakukan peran sebagi berikut peran pertama yaitu peran mutlak pengambil keputusan utama sebagai pemimpin bidang akademik di sekolah, dimana kepala sekolah adalah penentu dan pusat dari pembuatan dan pengambilan kebijakan utama di bidang akademik sekolah.

Peran kedua yaitu sebagai penghubung antara sekolah dengan yayasan, Hal tersebut dilakukan sebagai bentuk sebuah tindakan yang dilakukan bagi seorang pemimpin dalam lembaga pendidikan. Tindakan tersebut tidak lepas dari bentuk menjalin komunikasi agar tidak ada salah paham antar sekolah dengan yayasan. Dengan demikian kepala sekolah menangani semua manajerial didalam sekolah.

\section{Prosedur kepala sekolah dalam pembuatan keputusan di sekolah berbasis pesantren}

Hasil penelitian menemukan bahwa proses pembuatan keputusan yang dilakukan kepala sekolah di SMP An-nur yaitu menerapkan langkah-langkah sebagai berikut: (a) melakukan rapat pimpinan. (b) melakukan analisis perencanaan penyusunan konsep, (c) pengajuan kepada pihak yayasan, (d) alternatif pemecahan maslah, (e) alternatif terpilih (f) implementasi keputusan.

\section{Tipe kepala sekolah dalam pembuatan keputusan di sekolah berbasis pesantren}

Dalam penelitian di SMP An-Nur Bululawang peneliti menemukan beberapa tipe yang digunakan kepala sekolah SMP An-Nur Bululawang dalam pembuatan keputusan yaitu tipe demokratis. Tipe demokratis ini digunakan kepala sekolah SMP An-nur Bululawang untuk pembuatan keputusan dengan melibatkan bawahannya melalui rapat dan musyawaroh bersama untuk membahas pembuatan keputusan tersebut. Jadi tidak dibuat sendiri dan semena-mena oleh kepala sekolah.

Tipe kedua peneliti menemukan bahwa dalam pembuatan keputusan di SMP An-Nur Bululawang ini kepala sekolah juga memiliki wewenang untuk memutuskan sendiri (otoriter) tanpa melakukan koordinasi terlebih dahulu dengan bawahannya. Hal itu biasanya dilakukan oleh kepala sekolah SMP An-Nur pada saat memutuskan perkara atau kegiatan yang sifatnya ringan dan dilakukan sehari-hari. Sehingga kekuasaan wewenang sebagai pemimpin di sekolah tersebut muncul pada saat mengambil kebijakan sendiri tersebut.

Tipe ketiga yaitu tipe kekeluargaan yang yang digunakan oleh kepala sekolah SMP An-Nur Bululawang ini. Dalam hal ini ciri-ciri kepemimpinan kepala sekolah terlihat misalnya pada saat ada permasalahan sesuatu dalam untuk penyelesaiannya kepala sekolah mengambil keputusan dengan mengedepankan kekeluargaan di SMP An-Nur Bululawang tersebut. Dengan sistem kekeluargaan ini diharapkan kepala sekolah agar tidak terjadi perpecahan dan rusaknya hubungan kekeluargaan di SMP An-Nur sehingga tetap terjaga.

\section{Kendala dan solusi kepala sekolah dalam pembuatan keputusan di sekolah berbasis pesantren}

Kendala dan solusi yang dihadapi kepala sekolah SMP An-Nur Bululawang dalam melakukan pembuatan keputusan adalah sebagai berikut: pertama, adanya pedoman dari yayasan yang mempersempit dalam pergerakan pembuatan keputusan disekolah. Kedua, keputusan yayasan sulit dilakukan di lapangan sehingga apabila keputusan yayasan turun maka sekolah tetap melaksanakan dengan sesuai yang diberikan yayasan. Ketiga, adanya pro dan kontra terkait pelaksanaan keputusan yang baru diputuskan di sekolah sehingga kepala sekolah selalu memberikan sosialisasi dan penjelasan serta pengarahan terkait keputusan yang baru tersebut kepada warga sekolah dan harapannya agar menjadi terbiasa dan lebih baik. 


\section{PEMBAHASAN}

\section{Jenis-jenis keputusan di sekolah berbasis pesantren}

Hasil penelitian menunjukkan bahwa jenis keputusan di SMP An-Nur Bululawng Malang itu ada dua jenis kategori keputusan pertama apabila keputusan yang jenisnya akademik sekolah tanpa menyangkut kegiatan yayasan maka keputusan mutlak ada pada kepala sekolah sebagai pemimpin dan pengambil keputusan utama di SMP An-Nur Bululawang malang. kedua peneliti menemukan bahwa untuk keputusan sekolah yang menyangkut dengan kegiatan yayasan maka keputusan tidak hanya sampai di kepala sekolah saja melainkan kepala sekolah masih mengajukan kepada pihak pengasuh yayasan sehingga disini keputusan dan masukan juga bergantung pada pihak yayasan.

\section{Peran kepemimpinan kepala sekolah dalam pemimpin pembuatan keputusan di sekolah berbasis pesantren}

Hasil penelitian menunjukkan bahwa dalam pembutan keputusan di SMP An-Nur Bululawang ini kepala sekolah melakukan peran sebagi berikut peran pertama yaitu peran mutlak pengambil keputusan utama sebagai pemimpin bidang akademik di sekolah, dimana kepala sekolah adalah penentu dan pusat dari pembuatan dan pengambilan kebijakan utama di bidang akademik sekolah. Hal ini sesuai dengan yang diungkapkan oleh Mohajeran and Ghaleei (2008) bahwa kepala sekolah adalah pusat pengambilan keputusan utama di sekolah.

peran kedua yaitu sebagai penghubung antara sekolah dengan yayasan, Hal tersebut dilakukan sebagai bentuk sebuah tindakan yang dilakukan bagi seorang pemimpin dalam lembaga pendidikan. Tindakan tersebut tidak lepas dari bentuk menjalin komunikasi agar tidak ada salah paham antar sekolah dengan yayasan. Dengan demikian kepala sekolah menangani semua manajerial didalam sekolah. Hal tersebut didukung sesuai dengan teori yang disampaikan oleh Soetopo (2010: 70) yang mengemukakan bahwa (1) kepala sekolah sebagai pemimpin dalam bidang kurikulum, (2) kepala sekolah adalah pemimpin dalam bidang personalia, (3) seorang kepala sekolah adalah pemimpin bidang public relation, (4) kepala sekolah adalah pemimpin bidang hubungan guru dengan murid, (5) kepala sekolah adalah pemimpin bidang personil non pengajaran, (6) kepala sekolah adalah pemimpin dalam hungungan dengan dunia luar, (7) kepala sekolah adalah pemimpin dalam pengelolaan, pengorganisasian dan penggerakan di sekolah.

Selain itu berdasarkan penelitian tersebut maka peran kepala sekolah yang tertinggi sebagai pengambil keputusan utama di lingkungan akademik sekolah sebagai pemimpin dilembaga sekolah hal ini sesuai dengan teori yang disampaikan oleh Rivai (2007: 148) bahwa kepeimpinan kepala sekolah adalah seperangkat perilaku yang diharapkan dilakukan oleh kepala sekolah sebagai pemimpin tertinggi dalam sebuah lembaga pendidikan.

\section{Prosedur kepala sekolah dalam pembuatan keputusan di sekolah berbasis pesantren}

Hasil penelitian menemukan bahwa proses pembuatan keputusan yang dilakukan kepala sekolah di SMP An-nur yaitu menerapkan langkah-langkah sebagai berikut : (a) melakukan rapat pimpinan. (b) melakukan analisis perencanaan penyusunan konsep, (c) pengajuan kepada pihak yayasan, (d) alternatif pemecahan maslah, (e) alternatif terpilih (f) implementasi keputusan. Hal tersebut sesuai dengan pendapat yang dikemukakan oleh Simon 1997 (dalam Mustiningsih, 2014: 59) yang menggambarkan proses pembuatan keputusan terdiri atas 3 langkah diantaranya, (1) identifikasi dan pemilihan masalah, (2) pengembangan alternatif pemecahan masalah, dan (3) memilih alternatif pemecahan yang terbaik.

Temuan tersebut juga sesuai dengan teori yang dikemukakan oleh Stoner (dalam Engkoswara \& Komariyah, A, 2010: 112) bahwa ada beberapa langkah dalam pembuatan keputusan yaitu: (1) Definisi masalah, (2) diagnosis penyebabnya, (3) menentukan tujuan keputusan, (4) mengembangkan alternatif, (5) memilih alternatif terbaik, dan (6) implementasi keputusan.

\section{Tipe kepala sekolah dalam pembuatan keputusan di sekolah berbasis pesantren}

Tipe yang digunakan kepala sekolah SMP An-Nur Bululawang dalam pembuatan keputusan yaitu tipe demokratis. Tipe demokratis ini digunakan kepala sekolah SMP An-nur Bululawang untuk 
pembuatan keputusan dengan melibatkan bawahannya melalui rapat dan musyawaroh bersama untuk membahas pembuatan keputusan tersebut. Jadi tidak dibuat sendiri dan semena-mena oleh kepala sekolah. Hal ini sesuai dengan yang diungkapkan oleh Rivai (2007: 56-57) yaitu Tipe kepemimpinan demokratis ini merupakan tipe kepemiminan yang menempatkan manusia sebagai faktor utama dan terpenting dalam setiap kelompok, lembaga maupun organsiasi, juga sesuai dengan tipe kendali bebas yaitu Kepemimpinan dijalankan dengan memberikan kebebasan penuh pada orang yang dipimpin dalam membuat keputusan, baik secara perorangan maupun kelompok kecil.

Tipe kedua peneliti menemukan bahwa dalam pembuatan keputusan di SMP An-Nur Bululawang ini kepala sekolah juga memiliki wewenang untuk memutuskan sendiri (otoriter) tanpa melakukan koordinasi terlebih dahulu dengan bawahannya. Hal itu biasanya dilakukan oleh kepala sekolah SMP An-Nur pada saat memutuskan perkara atau kegiatan yang sifatnya ringan dan dilakukan sehari-hari. Sehingga kekuasaan wewenang sebagai pemimpin di sekolah tersebut muncul pada saat mengambil kebijakan sendiri tersebut. Hal ini sesuai dengan yang diungkapkan oleh oleh Rivai (2007: 56) bahwa tipe kepemimpinan otoriter, yaitu pada tipe ini menempatkan kekuasaan ditangan satu orang. Pemimpin bertindak sebagai penguasa tunggal. Kedudukan dan tugas anak buah semata-mata hanya sebagai pelaksana keputusan, perintah dan bahkan kehendak pimpinan.

Selain tipe ketiga peneliti juga menemukan ciri-ciri kekeluargaan yang yang digunakan oleh kepala sekolah SMP An-Nur Bululawang ini. Dalam hal ini ciri-ciri kepemimpinan kepala sekolah terlihat misalnya pada saat ada permasalahan sesuatu dalam untuk penyelesaiannya kepala sekolah mengambil keputusan dengan mengedepankan kekeluargaan di SMP An-Nur Bululawang tersebut. Dengan sistem kekeluargaan ini diharapkan kepala sekolah agar tidak terjadi perpecahan dan rusaknya hubungan kekeluargaan di SMP An-Nur sehingga tetap terjaga.

\section{Kendala dan solusi kepala sekolah dalam pembuatan keputusan di sekolah berbasis pesantren}

Peneliti menemukan Kendala dan solusi yang dihadapi kepala sekolah SMP An-Nur Bululawang dalam melakukan pembuatan keputusan adalah sebagai berikut: (a) adanya pedoman dari yayasan yang mempersempit dalam pergerakan pembuatan keputusan disekolah. (b) keputusan yayasan sulit dilakukan di lapangan sehingga apabila keputusan yayasan turun maka sekolah tetap melaksanakan dengan sesuai yang diberikan yayasan, (c) adanya pro dan kontra terkait pelaksanaan keputusan yang baru diputuskan di sekolah sehingga kepala sekolah selalu memberikan sosialisasi dan penjelasan serta pengarahan terkait keputusan yang baru tersebut kepada warga sekolah dan harapannya agar menjadi terbiasa dan lebih baik.

Dalam kendala-kendala diatas intinya terdapat pada komunikasi yang dilakukan oleh kepala sekolah sebagai pemmpin di lembaga pendidikan. Dalam hal ini Kepala sekolah sebagai leader harus mampu memimpin, memberikan petunjuk dalam peningkatan pendidikan, membuka komunikasi dua arah dan mendelegasikan tugas. Asrori (dalam Asmani, 2012: 34) mengemukakan bahwa kepala sekolah sebagai leader harus mempengaruhi orang-orang untuk kerjasama dalam mencapai tujuan bersama.

\section{SIMPULAN}

Kesimpulan penelitian ini terdiri dari lima fokus penelitian yaitu: (1) jenis-jenis keputusan di sekolah berbasis pesantren: (a) apabila keputusan yang jenisnya akademik sekolah tanpa menyangkut kegiatan yayasan maka keputusan mutlak ada pada kepala sekolah sebagai pemimpin dan pengambil keputusan utama di SMP An-Nur Bululawang Malang, (b) keputusan sekolah yang menyangkut dengan kegiatan yayasan maka keputusan tidak hanya sampai di kepala sekolah saja melainkan kepala sekolah masih mengajukan kepada pihak pengasuh yayasan sehingga disini keputusan dan masukan juga bergantung pada pihak pengasuh yayasan; (2) Peran kepala sekolah sebagai pemimpin dalam pembuatan keputusan di sekolah berbasis pesantren: (a) pertama yaitu peran mutlak pengambil keputusan utama 
sebagai pemimpin bidang akademik di sekolah, dimana kepala sekolah adalah penentu dan pusat dari pembuatan dan pengambilan kebijakan utama di bidang akademik sekolah, (b) peran kedua yaitu sebagai penghubung antara sekolah dengan yayasan, Hal tersebut dilakukan sebagai bentuk sebuah tindakan yang dilakukan bagi seorang pemimpin dalam lembaga pendidikan. Tindakan tersebut tidak lepas dari bentuk menjalin komunikasi agar tidak ada salah paham antar sekolah dengan yayasan; (3) Prosedur kepala sekolah dalam pembuatan keputusan di sekolah berbasis pesantren: (a) melakukan rapat pimpinan. (b) melakukan analisis perencanaan penyusunan konsep, (c) pengajuan kepada pihak yayasan, (d) alternatif pemecahan maslah, (e) alternatif terpilih (f) implementasi keputusan; (4) tipe kepemimpinan kepala sekolah dalam pembuatan keputusan di sekolah berbasis pesantren: (a) Tipe demokratis ini digunakan kepala sekolah SMP An-nur Bululawang untuk pembuatan keputusan dengan melibatkan bawahannya melalui rapat dan musyawaroh bersama untuk membahas pembuatan keputusan tersebut. Jadi tidak dibuat sendiri dan semena-mena oleh kepala sekolah, (b) Tipe kedua peneliti menemukan bahwa dalam pembuatan keputusan di SMP An-Nur Bululawang ini kepala sekolah juga memiliki wewenang untuk memutuskan sendiri (otoriter) tanpa melakukan koordinasi terlebih dahulu dengan bawahannya. Hal itu biasanya dilakukan oleh kepala sekolah SMP An-Nur pada saat memutuskan perkara atau kegiatan yang sifatnya ringan dan dilakukan sehari-hari. Sehingga kekuasaan wewenang sebagai pemimpin di sekolah tersebut muncul pada saat mengambil kebijakan sendiri tersebut, (c) tipe ketiga peneliti juga menemukan tipe kekeluargaan yang yang digunakan oleh kepala sekolah SMP An-Nur Bululawang ini. Dalam hal ini ciri-ciri kepemimpinan kepala sekolah terlihat misalnya pada saat ada permasalahan sesuatu dalam untuk penyelesaiannya kepala sekolah mengambil keputusan dengan mengedepankan kekeluargaan di SMP An-Nur Bululawang tersebut.

Dengan sistem kekeluargaan ini diharapkan kepala sekolah agar tidak terjadi perpecahan dan rusaknya hubungan kekeluargaan di SMP An-Nur sehingga tetap terjaga.; (5) kendala dan solusi kepala sekolah dalam pembuatan keputusan di sekolah berbasis pesantren: (a) adanya pedoman dari yayasan yang mempersempit dalam pergerakan pembuatan keputusan di sekolah sehingga sekolah selalu berusaha tetap mengacu pada pedoman dari yayasan tersebut, (b) keputusan yayasan sulit dilakukan di lapangan sehingga apabila keputusan yayasan turun maka sekolah tetap melaksanakan dengan sesuai yang diberikan yayasan, (c) adanya pro dan kontra terkait pelaksanaan keputusan yang baru diputuskan di sekolah sehingga kepala sekolah selalu memberikan sosialisasi dan penjelasan serta pengarahan terkait keputusan yang baru tersebut kepada warga sekolah dan harapannya agar menjadi terbiasa.

\section{DAFTAR RUJUKAN}

Asmani, J. M. 2012. Tips Menjadi Kepala Sekolah Profesional. Yogyakarta: Diva Press (Anggota IKAPI).

Engkoswara \& Komariyah. A. 2010. Administrasi Pendidikan, Bandung: Alfabeta.

Makawimbang, J. H.2010. Kepemimpinan Pendidikan yang Bermutu. Bandung: Alfabeta

Mohajeran, Behnaz and Ghaleei, Alireza. 2008. "Principal Role and School Structure" International Jurnal of Human and Social Sciences (Vol. 3 No.1), Page: 52-61.

Mustiningsih. 2014. Pembuatan Keputusan dalam Kepemimpinan Pendidikan. Malang: Fakultas Ilmu Pendidikan. Universitas Negeri Malang.

Nurkholis. 2008. Manajemen Berbasis Sekolah: Teori, Model dan Aplikasi. Grasindo.

Rivai, V. 2007. Kepemimpinan dan Perilaku Organisasi. Jakarta: PT. Raja Grafindo Persada.

Sugiyono. 2013. Metode PenelitianKuantitatif Kualitatif dan R\&D. Bandung: Alfabeta.

Suhardi, D. 2012. Peran SMP Berbasis Pesantren Sebagai Upaya Penanaman Pendidikan Karakter kepada Generasi Bangsa. Jurnal Pendidikan Karakter, 2(3): 316-328.

Schermerhorn, J. R., Hunt, J. G., dan Osborn, R. N. 2011. Organizational Behavior. Phoenix: University of Phoenix dan John Wiley \& Sons, Inc.

Soetopo, H. 2010. Kepemimpinan Pendidikan. Malang: Fakultas Ilmu Pendidikan Universitas Negeri Malang.

Ulfatin, N. 2015. Metode Penelitian Kualitatif di Bidang Pendidikan: Teori dan Aplikasinya. Malang: Media Nusa Creative. 